\title{
Evaluation of competencies for academic internship students
}

\author{
Harold Tinoco-Giraldo \\ GRIAL Research Group, Doctoral \\ Programme Education in the \\ Knowledge Society \\ Universidad de Salamanca \\ Salamanca, Spain \\ htinocogiraldo@usal.es
}

\author{
Eva María Torecilla sánchez \\ GRIAL Research Group, Research \\ Institute for Educational Sciences \\ Universidad de Salamanca \\ Salamanca, Spain \\ emt@usal.es
}

\author{
Francisco J.García-Peñalvo \\ GRIAL Research Group, Computer \\ Science Department, Research Institute \\ for Educational Sciences \\ Universidad de Salamanca \\ Salamanca, Spain \\ fgarcia@usal.es
}

\begin{abstract}
The rules and regulations on academic internships require all trainees to be "competent" and "qualified", but there is little direction on how institutions can prove that their workers and internship personal are knowledgeable and qualified. Competencies necessity to be correctly assessed, tested and verify, to fulfill the regulations of academic internship experiences, so that competencies continue to be assessed by a "competency standard", which specifies all the skills, talents, knowledge, abilities and experience required for each competency. This paper provides a competency assessments procedure used for academic internship practices.

Keywords-competency, assessment, academic internships, evaluation procedure
\end{abstract}

\section{INTRODUCTION}

All institutions need competent employees, especially when they are in their first academic internship, where errors can have disastrous consequences. Lack of certain competencies, skills and knowledge can contribute to serious accidents: it had been presumed that a trainee with a certain level of expertise and practice would be knowledgeable to do any task. This is a growing concern as institutions lose employees to retirement, work accidents, backlogs and staff reductions that in many cases mean more work for other employees and especially for interns.

Competence has always been key to protection and wellbeing [1]. The competency-based approach, as we all know, is an approach that has been known and developed for many years. In the 1970s, Bunk [2] introduced the term competency in the educational world; and he speaks of a competency as a way of showing that a person has skills and knowledge.

One of the first uses of the word "competences" is found in Classical Greece in a writing by Plato (Lysis 215 A, 380 AD). The root of the word is "ikano", a derivation of "iknoumai", which translates as "to arrive". In ancient Greece it had an

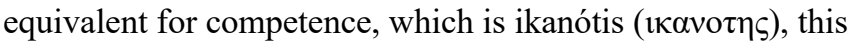
is the quality of being "ikanos" (capable), having the "ability to in order to achieve something", it is a skill. The origin of the term competence also appears in ancient Rome, from the Latin "competens", which means "to be able to".

The peculiarity of this word is that for many centuries it has always referred to labor and professional aspects and has not been used in educational terms until recent years. The concept of competence is therefore many centuries old, and achieving it has been the aspiration of many people throughout history in terms of work: to be professionally competent or what is the same, to be sufficiently capable and able to perform certain tasks with maximum efficiency.

The RAE dictionary [3] gives as meanings, in the first instance everything related to disputes, oppositions and rivalry. As a second meaning it provides everything related to expertise, aptitude and suitability to do something. Therefore, the educational conception we are looking for has not yet reached the dictionary, although this second definition is very close to what educational systems are currently looking for when educating by competencies, since the aim is for the student to "be able to". There have been three approaches to the term "competency" since the middle of the twentieth century: behaviorist, generic and cognitive. Today we have the same prominence on competence; for example, medical standards [4-5-6] oblige all workforce in an organization to be competent and qualified in all the responsibilities, tasks and assignments they execute.

\section{A. Competence}

A competence is a combination of skills (capability and know-how to do a job or a task); knowledge (ability to comprehend the job or the task); and, experience (interval of time performance the job or the task) [7-8-9]. A competence includes standards/actions/behaviors/assertiveness [10], and 'non-technical' skills (communication, decision-making, autonomous and team working, etc.) [11]. A competence is developed by a combination of guidance, mentoring, coaching, knowledge and experience [12].

\section{B. Qualification}

'Qualified' means a trainee evaluated [13]. According to Flaig et al. [14] a qualification is 'a recognized result of an assessment and authentication procedure which is gained when a competent organization regulates that an individual has accomplished learning outcomes to a given standard' ( $\mathrm{p}$. 99).

For this reason, in order for a practitioner/trainee to be called qualified in a competency, he/she must pass an evaluation (assessment) of that competency. So that to determine someone is competent does not necessarily mean to be qualified. Therefore, being qualified means that the competences of the trainee have been adequately assessed (evaluated).

\section{How to demostrate competence and qualification?}

Some individuals feel that they can demonstrate mastery/domain of their competencies by citing their 
academic and professional achievements, training programs completed and relevant experience [15]. Some individuals believe that they can demonstrate mastery of their competencies by citing their academic and professional achievements, training programs completed [16] and relevant experience [17], but presented in this way it creates a limitation because academic qualifications are only one academic feature of an individual's career history, and are not necessarily related to the job they are developing or will be performing as a trainee [18]. Thus, from this point of view, the demonstration of experience and qualification is inadequate and only allows rectifying this information by approaching external elements and individuals who may or may not recognize this skill presented by the individual [19]. A more accurate process is to have a competency assurance system that establishes appropriate competency standards and obliges to accomplish formal assessment and revision of previous evaluations.

\section{How to recognize competence in academic internships}

Many careers, rely on academic/professional credentials and qualifications, internship experiences, instructional programs, and on-the-job experience to develop or mastery competencies. Other careers demand the demonstration of the specific competences, such as medicine and nursing. This competency's validation is accomplished by completing practical, written and oral tests, carrying out exhaustive technical and professional simulations and to demonstrate the knowledge achieved by carrying out live practical exercises, such as laboratories [20]. Competence requires consistent practice [8][10]. Possessing certain competencies is limited to recognizing certain concepts, processes and principles, which sometimes require long practice to master [2] [10][12]. Knowledge factors are important, but they need to have a practical and domain-accurate context. Concepts are used to solve problems, and are part of each individual's RAM memory. Processes are attributed constant practice to achieve domain, but this will only allow an individual to be part of the process, and describe it. Competence in a process will include exchanging efforts, assessing conditions, solving failures, etc., to completely comprehend and appreciate the process [21].

\section{COMPETENCE ASSESSMENTE IN ACADEMIC INTERNSHIPS}

According to Crowell [22] an individual's competence cannot be grounded only on he/she own's personal evaluation. It has to be independently evaluated: “... men and women who aspire to be recognized as professionals require independent assessment of their competence when they are performing their internships processes...." (p-26). In the same way, Maker \& Zimmerman [23] consider that:

"To demonstrate competence in internship processes, students (trainees) must possess the necessary professional, personal experience, own technical skills, higher expertise, understand and execute behaviors required to perform a task or practical role, and be able to apply all these consistently and in accordance with stablished procedures and relevant internships' standards..." (p-259).
Assessment is a tool or process used to measure student/employee/trainee accomplishment of obtained learning outcomes [24]. The assessment procedure is a technical assessment and practical validation of understanding against "learning outcomes". This evaluative process ensures that trainees are competent to perform their academic, professional and job functions to an agreed standard [8]. There are various methods of assessing competencies; e.g., self-assessment; performance; examination; and, interview [12].

Evaluations shall be designed to assess the competencies of internships students or trainees using written, oral, practical, observational, or other trustworthy and objective means, and shall track a process that guarantees consistent direction of the assessments [25]. The evaluation strategy should guarantee the equivalence of the results of each evaluation, including content, validation of not only passing or failing the test, but also a degree of difficulty that allows to generate productive overthinking for each individual evaluated. This kind of evaluation strategy requires meticulous planning. The entire assessment strategy must be clearly organized, and detailed to the point of recognizing the minute details and steps in carrying out the assessment strategy [25]. The presence of an evaluator or mentor is indispensable when implementing an evaluation strategy [23]. Furthermore, it is essential to document the procedures to be tracked and the methodology to be followed to confirm the impartiality, validity, reliability and clarity of the evaluation. Table 1., shows the different processes used to assess competencies for internship students.

\section{TABLE I. ASSESSMENT TYPES}

\begin{tabular}{|c|c|}
\hline $\begin{array}{l}\text { Assessment } \\
\text { Types }\end{array}$ & Assessment validation in the internship \\
\hline $\begin{array}{l}\text { Self- } \\
\text { assessment }\end{array}$ & $\begin{array}{l}\text { The practicum student self-assesses his or her } \\
\text { competencies and subsequently has the opportunity to } \\
\text { acknowledge, compare and receive feedback on his or } \\
\text { her assessment with the subject matter expert assessor } \\
\text { or mentor chosen for this strategy [26]. }\end{array}$ \\
\hline $\begin{array}{l}\text { Observational } \\
\text { assessment }\end{array}$ & $\begin{array}{l}\text { Observational evaluation may be conducted by the } \\
\text { supervisor or immediate boss of the academic practice, } \\
\text { as well as the designated mentor. In this method of } \\
\text { assessment, the mentor observes, records and evaluates } \\
\text { the performance of the trainee over a long period of } \\
\text { time (depending on the strategy designed). This process } \\
\text { at certain levels and depending on the academic } \\
\text { practice, can be impractical and generate an unrealistic } \\
\text { evaluation [27]. }\end{array}$ \\
\hline $\begin{array}{l}\text { Assessment } \\
\text { by training }\end{array}$ & $\begin{array}{l}\text { The value of the training must be assessed; through a } \\
\text { written oral or practical examination and in many } \\
\text { settings, e.g., virtually or face to face. This type of } \\
\text { validation by examination is essential, as it is the only } \\
\text { evidence that recognizes that the trainees have } \\
\text { benefited from the training [28]. }\end{array}$ \\
\hline Interview & $\begin{array}{l}\text { Interviews with trainees are very useful because they } \\
\text { confirm instantly, clearly and at first hand the } \\
\text { professional competencies that the trainees possess, as } \\
\text { well as, their professional and/or academic weaknesses } \\
\text { and shortcomings. It can be conducted with technical, } \\
\text { practical, case studies or laboratories questions related } \\
\text { to the competencies to be assessed [21]. }\end{array}$ \\
\hline $\begin{array}{l}\text { Evidence- } \\
\text { based } \\
\text { assessment }\end{array}$ & $\begin{array}{l}\text { This evaluation can be carried out to measure or } \\
\text { compare one or several competencies. In order to } \\
\text { perform this evaluation, it is indispensable to design } \\
\text { tools with clear criteria to evaluate, judge, justify or } \\
\text { specify the performance of the competency level } \\
\text { required for the job/task in the internship process [29]. }\end{array}$ \\
\hline
\end{tabular}




\section{COMPETENCY EVALUATION PROCEDURE FOR STUDENTS IN ACADEMIC INTERNSHIPS}

The previous section showed the different types of assessment used for the competencies of academic internship students. The assessment has to be delimited in a process that guarantees and certifies reliable evaluation organization. This section presents a generic assessment procedure designed for students in academic internships.

A. Recognize the level of competency the student possesses

Interns should know what competencies they possess, and what level of professional and academic experience those competencies will enable them to perform a specific task in their academic internship. The specifications of the specific job in the academic internship recognize the skills and competency profile that the student must possess. Similarly, they can be recognized through continuous performance evaluations [12].

B. Assess the competencies of trainees against specific local or in some cases international standards

A trainee's competencies are assessed against a "competency standard". Competency standards stipulate a general description of a competency and include the skills, knowledge, expertise and experience necessary for a competency. Internship students with recognized and certified proof that fulfill these requirements can obtain a positive qualification in the domain of that competency. There are private, commercial and public bodies for the regulation of competency standards, such as, the Scottish Qualifications Authority [30], the Singapore Ministry of Education [31] and the European Commission/EACEA/Eurydice [32]. These standards are essential procedures to qualify and certify students in internship processes.

C. Demonstrate compliance with the standards set by these bodies

The practicum student must collect and certify that he/she meets the competency standards to perform the activities of the academic practicum. These proofs are essential, specific and must be presented in formats pre-established by the regulations, e.g., the Hague apostille or an international certification comparable to a notarization

\section{Find a competency assessor (mentor)}

Competency assessment must be done formally, and registered with a specific entity, e.g., a university. The competency assessment must be carried out by a subject matter expert (SME), mentor or a private, commercial and public body. This individual or body must be appropriately qualified and independent, and be able to validate the suitable understanding, capabilities, skills and expertise to accomplish the necessary assessments of the SME.

E. The evaluation process

From the evaluation, the evidence gathered is considered sufficient or insufficient to consider the level of competence of the student in academic practice. If the evidence is insufficient, the student must take a formal test-type evaluation to recognize his/her level. The competency standards provided by the bodies contain the necessary details of the competency level that the candidate and/or student must possess. As Table 1 mentions, there are several methods to assess competencies (self-assessment, observation, assessment by training and interview).
F. Recognition: When the assessed student passes the standardized test and meets the requirements of the standard, he/she is awarded a proficiency level qualification (beginner, foundation, professional).

\section{E-MENTORING PROGRAM IN ACADEMIC INTERNSHIPS ASSESMENT PROCESS}

The E-Mentoring in Academic Practices program is a learning strategy that has the function of recognizing and advising students in academic internships in the development of their professional competencies in training, the level of mastery they possess and also, it provides a clear evaluation strategy that helps these students to achieve the different competency levels issued by the regulations established by the European Commission/EACEA/Eurydice [32].

The individual can obtain as results after the mentoring process a demonstrable recognition of the level of competence mastery that he/she had at the beginning of his/her academic internship and at the end of it after having participated in the e-mentoring program. The competencies evaluated are shown in Table 2.

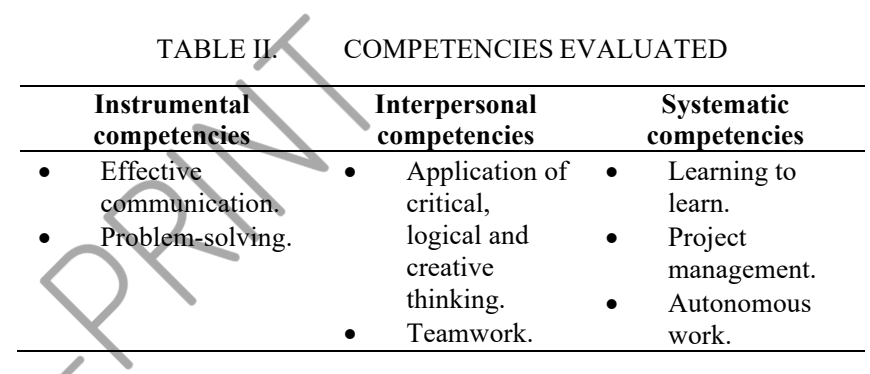

European Commission/EACEA/Eurydice [32], competency standards were compulsory and provided the steps of the competency evaluation procedure for students in academic internships. The assessment, SMEs and recognitions were provided by the E-Mentoring program in Academic Internships [12]. The evaluation process is shown in Table 3.

\section{TABLE III. ASSESSMENT PROCESS}

\begin{tabular}{cl}
\hline Step & \multicolumn{1}{c}{ Detail } \\
\hline 1 & $\begin{array}{l}\text { Internship student applies to the E-mentoring Program in } \\
\text { Academic Internships for an assessment of a competency(ies). }\end{array}$ \\
\hline 2 & $\begin{array}{l}\text { Internship student is sent auto-assessment with list of } \\
\text { competencies to evaluate (confidentiality requirements). }\end{array}$ \\
\hline 3 & $\begin{array}{l}\text { Internship student recognizes his/her Competencial level } \\
\text { (beginner, foundation, professional) that he/she believes } \\
\text { possesses. }\end{array}$ \\
\hline 4 & $\begin{array}{l}\text { E-mentoring Program in Academic Internships sends the selected } \\
\text { European Commission/EACEA/Eurydice Competency Standard } \\
\text { to the internship student. }\end{array}$ \\
\hline 5 & $\begin{array}{l}\text { Internship student verifies if he/she meets the qualifications, pre- } \\
\text { requisites and co-requisites of } \\
\text { Commission/EACEA/Eurydice Competency Standard. }\end{array}$ \\
\hline 6 & $\begin{array}{l}\text { Internship student completes and sends assessment to be } \\
\text { evaluated. }\end{array}$ \\
\hline 7 & $\begin{array}{l}\text { E-mentoring Program in Academic Internships coordinator } \\
\text { decides to evaluate the student, after consideration of required of } \\
\text { qualifications, pre-requisites and co-requisites and in some cases } \\
\text { he/she requires interviews with the student. }\end{array}$ \\
\hline 8 & $\begin{array}{l}\text { E-mentoring Program in Academic Internships coordinator } \\
\text { appoints a mentor(s). }\end{array}$ \\
\hline $\begin{array}{l}\text { E-mentoring Program in Academic Internships coordinator sends } \\
\text { a competency rubric assessment form to the mentor (s) to be } \\
\text { assessed. }\end{array}$ \\
$\begin{array}{l}\text { Internship student signs a Consent of participation (confirming } \\
\text { that the evidence submitted is correct and accurate) and sends it } \\
\text { to the E-mentoring Program coordinator. }\end{array}$ \\
\hline
\end{tabular}




\begin{tabular}{cl}
\hline 11 & $\begin{array}{l}\text { Internship student is assessed on an agreed date by him/herself } \\
\text { and the appointed mentor. }\end{array}$ \\
\hline 12 & $\begin{array}{l}\text { E-mentoring Program coordinator informs student of results of } \\
\text { assessment. }\end{array}$ \\
\hline 13 & $\begin{array}{l}\text { E-mentoring Program coordinator recognizes and certifies the } \\
\text { assessed competency (ies) }\end{array}$ \\
\hline 14 & $\begin{array}{l}\text { E-mentoring Program coordinator draws up a certificate of } \\
\text { successful completion of the evaluation as proof of the } \\
\text { evaluation. }\end{array}$ \\
\hline
\end{tabular}

The internship students finished their competency evaluations, and a new cycle of further evaluation in other competencies is initiated to demonstrate their competency level.

\section{DISCUSSION AND CONCLUSIONS}

Some institutions recognize and fully believe in the primary academic qualifications provided by ad hoc training programs and on-the-job experience to develop competencies. It is important to recognize that this approach is outdated, especially for the recognition of competency levels of students in academic internship programs. As stated by the European Commission/EACEA/Eurydice [32] "Qualification is an end; training is the means to an end.... Qualification is the outcome of assessment; training does not necessarily result in qualification." Currently, the demonstration of the competency levels of practitioners is done through assessment [33]. An assessed, certified and mastered competency becomes a qualification [26]. A learner who claims to possess a competency, without possessing verification with credible evidence such as an assessment, is recognized as unqualified in that competency [34-35].

The value of competency assessment is evident, and to achieve it, it is essential to follow the rules and regulations that the international recognized bodies offer to assess the competency levels of academic internships. According to O'Neill \& Padden [25] assessments have many benefits:

- Concrete evidence of standards and regulatory compliance.

- The requirements it utilizes target the acquisition of skills, knowledge and experience.

- Promotes help to trainees to develop their own professional careers.

- Underwrites tests based on competency assessments.

- It has a quantitative basis for training and research requirements.

The requirements for each competency, their levels of mastery and assessments are part of the "competency framework" of the e-mentoring program [21]. In fact, following the European Higher Education Area [36] points out that for trainees to actively participate in the academic and practical processes "competence management systems" must be in place in an individual support program presented by a higher education institution [37], e.g., a mentoring program.

On the other hand, Rios et al. [38] argue that competency assessment, like any other assessment, cannot be considered perfect or adequate if the assessment procedures do not fit the needs of institutions, practitioners, and especially academic practice entities (businesses and institutions).

For Maker and Zimmerman [23] to achieve this adequate form of assessment, it must be guided by a well-designed competency assessment program that is supported by all participants and is part of a formal mentoring program. Only in this way, the authors emphasize, will well-documented competency assessments enable competency management focused on fairness, safety and truth [39].

\section{REFERENCES}

[1] M. Wright, D. Turner and C. Horbury. Competence assessment for the hazardous industries (pp. vii-xvi). HSE Books.2003

[2] G. Bunk."La transmisión de las competencias en la formación y perfeccionamiento profesionales de la RFA". Revista Europea de Formación Profesional, vol. 1, no. 94, pp. 8-14, 1994

[3] RAE. http://www.rae.es. Edición 23a, octubre 2014.

[4] P. Batalden, D. Leach, S. Swing, H. Dreyfus and \& S. Dreyfus. "General competencies and accreditation in graduate medical education. Health affairs, vol. 21, no. 5, pp. 103-111. 2002

[5] M. Montagnini, H. Smith, D. Price, B. Ghosh and L. Strodtman. "Selfperceived end-of-life care competencies of health-care providers at a large academic medical center". American Journal of Hospice and Palliative Medicine $\AA$, vol. 35, no. 11, pp.1409-1416. 2018

[6] J. Van Der Aa, A. Aabakke, B. Andersen, A. Settnes, P. Hornnes, P., $P$. Teunissen and F. Scheele. "From prescription to guidance: a European framework for generic competencies". Advances in Health Sciences Education, vol. 25, no. 1, pp. 173-187. 2020

[7] R. Roe. "What makes a competent psychologist?" European Psychologist, vol. 7, no. 3, pp. 192-202. 2002

[8] J. Mateo."Interpretando la realidad, construyendo nuevas formas de conocimiento: El desarrollo competencial y su evaluación". Revista de Investigación Educativa, vol. 25, no. 2, pp. 513-531. 2007

[9] J. Gacel-Ávila. "The impact of the Bologna Process on higher education in Latin America". International Journal of Educational Technology in Higher Education, vol. 8, no. 2, pp. 285-296. 2011. https://dot.org/10.7238/rusc.v8i2.1092

[10] J. Tejada Fernández and C. Ruiz Bueno. "Significación del prácticum en la adquisición de competencias profesionales que permiten la transferencia de conocimiento a ámbitos propios de la acción docente". Profesorado. Revista de Curriculum y Formación de Profesorado, vol. 17, no. 3, pp. 91-110. 2013. ttps://doi.org/10.5944/educXX1.12175

[11] S. Tobón. "Aspectos básicos de la formación basada en competencias". Talca: Proyecto Mesesup, no. 1, pp. 1-15. 2006

[12] H. Tinoco-Giraldo, E. M. Torrecilla Sánchez and F.J. García-Peñalvo. "Utilizing technological ecosystems to support graduate students in their practicum experiences" Sixth International Conference on Technological Ecosystems for Enhancing Multiculturality, Salamanca, Spain, October 12, 2018, https://doi.org/10.1145/3284179.3284344

[13] D.Makovec."The teacher's role and professional development". International Journal of Cognitive Research in Science, Engineering and Education, vol. 6, no. 2, p. 33. 2018

[14] M. Flaig, B. Simonsmeier, A.Mayer, T. Rosman, J. Gorges and M. Schneider. "Reprint of Conceptual change and knowledge integration as learning processes in higher education: A latent transition analysis". Learning and Individual Differences, 66, pp. 92-104. 2018

[15] C. M. Rodríguez. "The impact of academic self-concept, expectations and the choice of learning strategy on academic achievement: the case of business students". Higher Education Research \& Development, vol. 28, no. 5,pp. 523-539. 2009

[16] B. Giridharan. Learning for a Sustainable Future: Developing Key Competencies. In Introduction to Sustainable Development Leadership and Strategies in Higher Education. Emerald Publishing Limited. 2020

[17] U. Trautwein, O. Lüdtke, O. Köller and J. Baumert. "Self-esteem, academic self-concept, and achievement: How the learning environment moderates the dynamics of self-concept". Journal of Personality and Social Psychology, vol. 90, no. 2, pp. 334-368. 2006

[18] J. Teixeira da Silva, J. Dobránszki, A. Al-Khatib and P. Tsigaris, "Curriculum vitae: challenges and potential solutions". KOME: An International Journal of Pure Communication Inquiry, vol. 8, no. 2, pp. 109-127. 2020

[19] L. Spencer and P. Spencer. Competence at work models for superior performance. John Wiley \& Sons. 2008 
[20] J. Hansen and M. Bratt. "Competence acquisition using simulated learning experiences: A concept analysis". Nursing Education Perspectives, vol. 36, no. 2, pp.102-107. 2015

[21] H. Tinoco-Giraldo, E. M. Torrecilla Sánchez and F.J. García-Peñalvo "Evaluación de la percepción de los niveles de dominio competencial en práctica laboral. Estudios Pedagógicos (Valdivia), vol 46, no. 1, pp. 127-144. 2020. http://dx.doi.org/10.4067/S0718-07052020000100127

[22] T.L. Crowell. Academic internships: To take or not to take? Students' assessments of public health fieldwork. Pedagogy in Health Promotion, vol 4, no. 1, 19-34. 2018.

[23] C. Maker. And R. Zimmerman. "Concept maps as assessments of expertise: Understanding of the complexity and interrelationships of concepts in science". Journal of Advanced Academics, vol. 31, no. 3 , pp. 254-297. 2020

[24] K. McGlynn and J. Kelly."Using formative assessments to differentiate instruction." Science Scope, vol. 41, no. 4, pp. 22-25. 2017

[25] G. O'Neill and L. Padden. "Diversifying assessment methods: Barriers, benefits and enablers". Innovations in Education and Teaching International, pp. 1-12. 2021.

[26] A. Kazley, L. Dickerson and J. Zoller. "Student Competency SelfAssessment Measurement: Frame of Reference is Everything". The Journal of Health Administration Education, vol. 33, no. 1, 201-229. 2016

[27] T. Swindle, J. Phelps, N. McBride, J. Selig, J. Rutledge and S. Manyam. "Table Talk: revision of an observational tool to characterize the feeding environment in early care and education settings". BMC Public Health, vol. 21, no. 1, pp. 1-11. 2021

[28] S. Meeuwissen, R. Stalmeijer and M. Govaerts. Multiple-role mentoring: mentors' conceptualisations, enactments and role conflicts. Medical Education, vol. 53, no. 6, pp. 605-615. 2019.

[29] M. Ramis, A. Chang, A. Conway, D. Lim, J. Munday and L. Nissen, "Theory-based strategies for teaching evidence-based practice to undergraduate health students: a systematic review". BMC Medical Education, vol. 19, no. 1, pp. 1-13. 2019.

[30] Scottish Qualifications Authority (SQA). Key competencies - some international comparisons. Bulletin number 2: Policy and Research. 2003. www.sqa.org.uk/files ccc/Key Competencies.pdf.

[31] Singapore Ministry of Education. Framework for 21 st century competencies and student outcomes. 2010. www.moe.gov.sg/ education $/ 21 \mathrm{cc} /$.
[32] European Commission/EACEA/Eurydice. Developing Key Competences at School in Europe: Challenges and Opportunities for Policy. 2012.https://www.ddooss.org/informes/School_in_Europe.pdf

[33] J. Jani, P. Osteen and S. Shipe. "Cultural competence and social work education: Moving toward assessment of practice behaviors". Journal of Social Work Education, vol. 52, no. 3, pp.311-324. 2016.

[34] M. Usart Rodríguez, J. lázaro Cantabrana and M. Gisbert Cervera. "Validation of a tool for self-evaluating teacher digital competence”. Educación XXI, vol. 24, no. 1, pp. 353-373. 2021

[35] H. Tinoco-Giraldo, E. M. Torrecilla Sánchez, and F. J. García-Peñalvo, "E-Mentoring in Higher Education: A Structured Literature Review and Implications for Future Research," Sustainability, vol. 12, no. 11, 2020, Art no. 4344, doi: 10.3390/su12114344.

[36] R. Ferreras-Garcia, J. Sales-Zaguirre and E. Serradell-López. Analysing Competencies by Gender in Internships. In Research and Innovation Forum 2020: Disruptive Technologies in Times of Change (pp. 411-419). Springer International Publishing. 2021

[37] F. J. García-Peñalvo and A. M. Seoane-Pardo, "An updated review of the concept of eLearning. Tenth anniversary," Education in the Knowledge Society, vol. 16, no. 1, pp. 119-144, 2015, doi: 10.14201/eks2015161119144.

[38] J. Ríos, G. Ling, R. Pugh, D. Becker and A. Bacall. "Identifying critical 21st-century skills for workplace success: A content analysis of job advertisements". Educational Researcher, vol. 49, no. 2, pp.80-89. 2020

[39] E. Crisol-Moya, L. Herrera-Nieves, and R. Montes-Soldado, "Educación virtual para todos: una revisión sistemática," Education in the Knowledge Society, vol. 21, 2020, Art no. 15, doi: 10.14201/eks.20327.
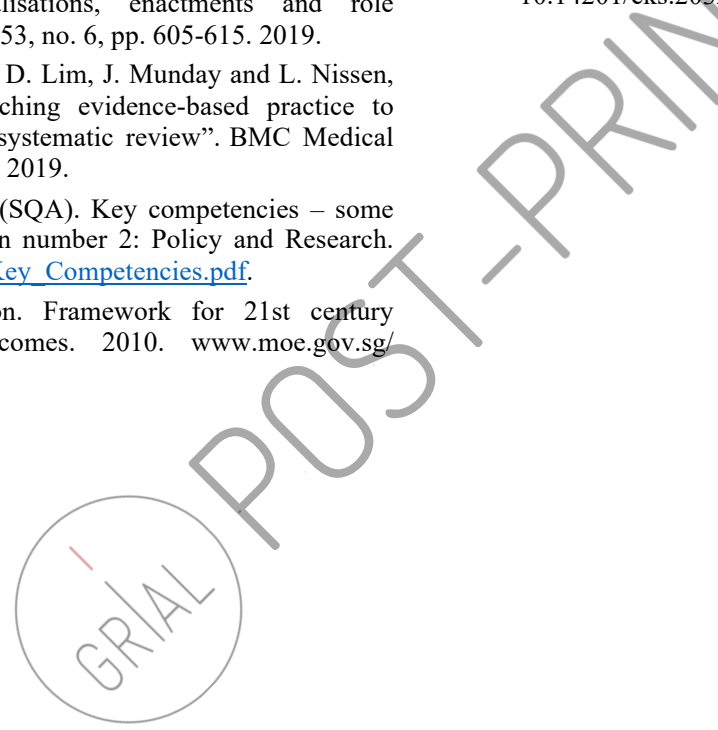